\title{
Investigating The Use of Smartphone Disorders in Learning by Students of Mechanical Engineering Expertise Program (MEEP)
}

\author{
Sapitri Januariyansah ${ }^{1}$, Dwiki Muda Yulanto ${ }^{2}$, Safri Gunawan ${ }^{3}$, Hanapi Hasan ${ }^{4}$, Henry \\ Iskandar $^{5}$ \\ Universitas Negeri Medan, Indonesia ${ }^{12345}$ \\ sapitrijanuariyansah@unimed.ac.id
}

\begin{abstract}
The use of smartphones by MEEP students is expected to help the learning process. However, whether the smartphone can really help the learning process or even give a negative impact? This study is to describe the use of smartphones by MEEP students in learning. The type of research is Sequential Explanatory Design with Mixed Method Approach. The result of this research is the level of disruption of smartphone usage by MEEP students in general learning into the high category (mean count (3.32) > mean ideal (2.5)). It means that the use of smartphones by MEEP students has a negative impact on learning. Negative impacts that happened (as a medium for playing mobile games and social media) were more dominant than positive impacts. The use of smartphones by MEEP students cannot be stopped. However, students can be directed to use smartphones in a healthy way.
\end{abstract}

Keywords: smartphone; MEEP students; learning process

\section{Introduction}

Smartphone is one of technological developments that occur in the present era. Smartphones become one of the smart technologies that are widely used by all circles because the selling price of smartphones is affordable. Actually, this smartphone is supported by internet technology and technology Operational System (OS) that allows the smartphone can work like a computer in a mini version. The Internet has been introduced worldwide globally since the 1990s [1]. The global use of the Internet allows each user to access information. While the OS which is the IOS OS and Android OS became the main choice since the 2000s. Therefore, in addition of the communication media such as telephone, short message service, and social media, smartphone can also access a lot of information and run other virtual media in a state connected to the internet or not. OS of a smartphone combined with quality hardware, also helps in optimizing the performance of smartphones. The features and ease of using the smartphone make it as one of the tools used in education, especially in the learning process.

The learning process is in desperate need of media as a means to make learning more interesting, effective, and efficient. The media used can be either conventional media or interactive media based on technology. However, in the present, the often-used learning media is interactive media with the help of technology. Learning media in the form of software can 
improve the students' learning outcomes which mean that there is a positive effect on learning by utilizing technology [2]. At present the technology that is popular to improve learning is mobile technology such as tablet/iPad and smartphone. It is because this technology is more practical and has a high mobility. The use of mobile technologies such as tablets/iPads and smartphones can increase students' engagement in learning [3]. Smartphones can also inspire, motivate, provoke curiosity and invite a substantial reading that will enhance students' complex reading skills [4].

Basically, the use of smartphone technology by students of Vocational High School of Mechanical Engineering Expertise Program is unavoidable. This happens because they are the $\mathrm{Z}$ generation that has the ability to use good technology including smartphones. The $\mathrm{Z}$ Generation has the characteristics that: (1) Convenient and highly dependent on technology, this is because Z Generation grows surrounded by technology; (2) Multitasking with various online products, advanced technology tools, respect for simplicity, and interactive design; (3) have a higher social responsibility for the amount of information obtained online; and (4) always connected to social networks [5]. Smartphones are not only used at home students but also it is used at school in the learning process. The use of smartphones in learning can also help the learning process of students such as teacher and student discussion media, sender and recipient of teaching materials, and as a media browser material and video education (tutorial). Based on the explanation above, it can be said that the smartphone has a positive impact for MEP students in learning. However, does the use of smartphones in learning really give just a positive impact and not have a negative impact? Is the smartphone's positive impact greater than its negative impact, or the vice versa? And how to manage the smartphone usage positively in the Z generation that grows along with the development of technology since childhood?

Media-based learning technology is considered to help the learning process. The use of technology in learning has been widely used such as technology in education can improve teaching practice and student performance [6]. Technology is usually used as a learning media that become one of the focuses of the development in the world of education today. However, in the development of technology-based media in learning cannot be made arbitrarily, but required special designs that fit the needs of students. Its function is as the media to be effective and efficient. The design of effective learning media is to consider various aspects of the environment such as the application of domain knowledge, conceptual theory, and evaluation of the quality of the overall designed environment [7].

The use of technology such as smartphones and the internet as a learning media is actually very central lately. YouTube and Social Media can be an instruction media with the notion that teachers must conditioned the form of the direct learning, constructivist and participatory learning approach of integrating potential social media affordances [8]. On the other hand, elearning as a technology-based learning media that can be accessed through computers, laptops, tablets, and smartphones is one of the learning media used by MEP students. However, elearning as a learning media for MEP students has a special design that must be fulfilled which has four main aspects, namely aspects of needs analysis, selection and order of competence, learning development, and evaluation of learning [9]. Based on the above studies, the smartphone is clearly an ideal media as a learning media.

The use of smartphones other than as a communication tool by the school apparatus, smartphones are also commonly used as a learning media in the classroom. Features of smartphones such as mobile internet access, offline and online information media, as social media such as sms, chat, call, video call, and group chat access, as a media to run software aids to learn, and as a media entertainment video player, games, and so forth. The use of smartphones as a learning media in this era cannot be avoided as an example of a smartphone can be a media 
for ubiquitous learning (u-learning) with the excellent of smartphone that is owned by almost users as well as the nature of a versatile smartphone and compatibility [10]. The use of smartphones can also enhance critical thinking, creative thinking, communication, and learners' collaboration skills [11]. Students use their smartphones to access teaching materials or supporting information, which is usually accessible via the Internet. Students use smartphones as learning assistances for many reasons such as providing convenience, portability, comprehensive learning experience, multi-source and multitasking, and environmentally friendly. [12]. The advantages of smartphone in learning can also be combined with a software. The combination of learning applications and smartphones is very helpful in learning such as Scorative application that is student response system that allows teachers to create quizzes and online interactive games to students so as to generate real-time assessment of the students' learning, motivation of the students and support to opportunities for active learning [13]. Based on the studies above, it can be said that smartphone is a media that can support learning. However, the use of smartphones as a learning media does not always have a positive impact on learning.

The negative effect of smartphones is that smartphones provide negative psychological effects which make someone become addicted to smartphones like the use of social media and instant communication dependence, one forgets how to face to face interaction [14]. Other negative impact on academic performance of higher learning students because students become addicted to social media like Facebook, Twitter, Instagram, WhatsApp and the like without considering the time (5-7 hours a day) [15]. A study suggests that students consider the use of smartphones in the classroom to improve their focus, concentration, and learning engagement, whereas the reality of smartphones becomes opium and distraction for them. It is therefore advisable to provide the correct use of smartphones or to seize student smartphones during classroom learning in order to enhance a conducive classroom atmosphere, focus on learning and student attention [16].

Another supportive study conducted on students that students consider the use of smartphones in the classroom can improve the focus, concentration, and involvement of their learning, when in fact the smartphone becomes opium and interference for them. It is therefore advisable to extract the knowledge of the correct use of smartphones or to seize student smartphones during classroom learning in order to improve the conducive classroom atmosphere, focus on learning and student attention [17]. In fact, internet addiction can lead to suicide. Survey conducted to 631 people ages $12-18$ years as many as $30.2 \%$ of them are users who are addicted to the internet. The results show that the cause of the idea of suicide is the state of sleepless students caused by Internet addiction [18].

Another negative effect of smartphones as the study that has been done to students that smartphones have negative effects on students' academic performance even though they were used for school-related learning activities. In fact, it was found that the students utilized their smartphones for university learning activities, on the lower their CGPA. The use of a smartphone is definitely a dominant cultural staple of this generation of university students. They use the smartphone during class time, while completing homework and while studying [19]. Based on the studies above, smartphone also gives negative impact both on the side of health and learning. The studies above were conducted against those of the millennial generation, then what about the more intense $\mathrm{Z}$ generation in the use of technology such as smartphones.

In general, MEP Students are currently aged 13-18 years. The children of Primary School are those between the ages of 6 and 13, subsequently, for the ages of 14 years to 17 years in the juvenile category [20]. Ages 13-18 years are teenagers who are the age of MEP students which 
means they are people of the $\mathrm{Z}$ generation, because $\mathrm{Z}$ Generation is a generation born from 1990 to mid 2010 [21]. The $\mathrm{Z}$ Generation has the characteristics of having good multitasking capabilities where this generation is one generation that experienced a change from the traditional era to the digital era. The $\mathrm{Z}$ Generation basically has similarities with the $\mathrm{Y}$ generation, but what makes the difference is the $\mathrm{Z}$ generation is very superior in applying all activities such as using social media, using the phone, browsing using a PC where everything they do is related to the virtual world [22]. The $\mathrm{Z}$ Generation is also known as digital natives that are people who are very familiar with digital technology since birth [23]. If you look at the characteristics of the $\mathrm{Z}$ generation, it is impossible for teachers and parents to separate smartphones from their daily lives both in school and outside school.

\section{Research Method}

This research used survey method with quantitative approach. The selection of such methods was to look at the use of smartphones by students during the learning process. The location of research that has been done is at Vocational High School (VHS) Mechanical Engineering Expertise Program (MEEP) in Daerah Istimewa Yogyakarta (DIY). The sampling technique used is purposive sampling. This selection is based on the Mechanical Engineering Expertise Program as one of the Education Program based on technology and DIY as one of the education centers in Indonesia. Researchers chose one MEEP in each one city and four districts in DIY. Furthermore, the researcher selects one class on each MEEP as representative. The selected class is class XI because the students who are in the class are those who have experienced in learning longer than from class $\mathrm{X}$ and have a more effective learning process from class XII. The type of class chosen was a class of theoretical learning because students in the theoretical learning class can use many methods and learning media. Those methods and media used such as smartphones rather than the classroom practice where students tend to interact more with tools and practical machines only. Based on the explanation, the object of research is the disorder of the use of smartphones by students on 5th grade XI in the learning process.

Furthermore, the subjects of the study were the students and teachers who followed the learning process in 5 selected theoretical classes. The number of teachers selected was one person in each class leading the learning process. Then, the number of students selected was based on all students who follow the learning process to be observed. However, in the interview process only four students selected as representatives with the indicators of selection. Those indicators were the students who actively used the smartphone during the learning process happened.

Data collection technique in this research was observation method supported by interview method. Validity of observation instrument used content validity with Aiken's V analysis. Reliability is conducted by Intraclass Correlation Coefficient (ICC) technique. Observation methods were used to see the real state of smartphone usage at the time the learning takes placed by students in the classroom. The type of observation used in this research was passive participation observation that researchers observe from within the classroom by looking directly at the students' activities while the teaching and the learning process without getting involved in learning activities. The number of observation items was 5 items with a minimum value of 4 and a maximum value of 20 . Researchers chose as many as 3 people as an observer in each class. 
Furthermore, the interview method to confirm and to know more about the use of smartphones was applied as supporting data. Interviews were conducted referring to the state of the student in using smartphones and how the smartphones were used. In addition, interviews were also conducted to the teachers to confirm the observation results. Furthermore, the data obtained were analyzed by quantitative descriptive analysis technique by finding the mean value, the standard deviation, and the criteria of research results (the ideal average was 2.5 and the ideal Std. average was 0.5 ). The criteria of research results were grouped in four categories that were very high, high, medium, and low.

\section{Results and Discussion}

\subsection{Results}

Based on the results of the observation, the data analysis was obtained the average value of each school was greater than the ideal average value set (2.5). This showed that the disorder of the use of smartphones in the classroom in general high category, so the use of smartphones in the classroom has not fully helped the learning process. Therefore, the smartphones in detail also have the same negative impact on every VHS. The result of observation data can be seen on table 1 .

Table 1. The Results of Interference Data of Smartphone Usage in Learning

\begin{tabular}{|c|c|c|c|c|c|c|}
\hline \multirow[b]{2}{*}{ Name } & \multirow[b]{2}{*}{ Mean } & \multirow{2}{*}{$\begin{array}{c}\text { Standard } \\
\text { Deviasi }\end{array}$} & \multicolumn{4}{|c|}{ Criteria } \\
\hline & & & $\begin{array}{l}\text { Very } \\
\text { High }\end{array}$ & High & Middle & Low \\
\hline VHS MEEP DIY & 3.32 & 0.08 & $67 \%$ & $33 \%$ & $0 \%$ & $0 \%$ \\
\hline $\begin{array}{l}\text { MEEP Yogyakarta City } \\
\text { (VHS 1) }\end{array}$ & 3.40 & 0.35 & $67 \%$ & $33 \%$ & $0 \%$ & $0 \%$ \\
\hline $\begin{array}{l}\text { MEEP Sleman Regency } \\
\text { (VHS 2) }\end{array}$ & 2.93 & 0.30 & $0 \%$ & $67 \%$ & $33 \%$ & $0 \%$ \\
\hline $\begin{array}{l}\text { MEEP Bantul Regency } \\
\text { (VHS 3) }\end{array}$ & 3.73 & 0.11 & $100 \%$ & $0 \%$ & $0 \%$ & $0 \%$ \\
\hline $\begin{array}{l}\text { MEEP Gunung Kidul } \\
\text { Regency (VHS 4) }\end{array}$ & 3.27 & 0.23 & $67 \%$ & $33 \%$ & $0 \%$ & $0 \%$ \\
\hline $\begin{array}{l}\text { MEEP Kulonprogo } \\
\text { Regency (VHS 5) }\end{array}$ & 3.27 & 0.11 & $33 \%$ & $67 \%$ & $0 \%$ & $0 \%$ \\
\hline
\end{tabular}

Further discussion is to see the average value of criteria from the observation instrument that can be seen in table 2 . 
Table 2. The Results of Interference Data of Smartphone Usage in Learning based on indicators

\begin{tabular}{llllllll}
\hline \multicolumn{1}{c}{ Criteria } & \multicolumn{5}{c}{ Mean of Calculation } \\
\cline { 2 - 7 } & $\begin{array}{c}\text { MEEP } \\
\text { DIY }\end{array}$ & VHS 1 & VHS 2 & VHS 3 VHS 4 VHS 5 \\
\hline $\begin{array}{l}\text { Students play a smartphone when the } \\
\text { teacher explained the learning materials. }\end{array}$ & 3.07 & 3.33 & 2.67 & 3.67 & 2.67 & 3.00 \\
\hline $\begin{array}{l}\text { Students do not focus when the learning } \\
\text { process caused by the smartphones. }\end{array}$ & 3.53 & 3.33 & 3.00 & 4.00 & 3.67 & 3.67 \\
\hline $\begin{array}{l}\text { Students do not use smartphone as a } \\
\text { learning assistant. }\end{array}$ & 2.60 & 2.67 & 2.33 & 3.00 & 2.67 & 2.33 \\
\hline $\begin{array}{l}\text { Students who use smartphones in the } \\
\text { classroom tend to disturb other students. }\end{array}$ & 3.73 & 4.00 & 3.00 & 4.00 & 3.67 & 4.00 \\
\hline $\begin{array}{l}\text { There is no fixed regulation about the use } \\
\text { of smartphone in the classroom. }\end{array}$ & 3.67 & 3.67 & 3.67 & 4.00 & 3.67 & 3.33 \\
\hline
\end{tabular}

Based on table 2 it is known that: (1) Item 1 generally receives an average value above the ideal average value (2.5) which means that the level of smartphone usage by students during the learning process is categorized high; (2) Item 2 generally obtains an average score above the ideal mean (2.5) which means that the concentration level of student learning is not focused due to the smartphone which categorized into the high category; (3) Item 3 generally obtains an average value above the ideal mean (2.5) which means that the level of smartphone usage is not as a tool included in the high category. However, when it is viewed in more detail there are two MEEP that get an average score below the ideal mean which means the students in the MEEP are on average using a smartphone for the learning process; (4) Item 4 generally obtains a mean value above the ideal (2.5) which means that the rate of the smartphone usage by students tends to disturb other students including in the high category; and (5) Item 5 generally receives an average value above the ideal average value which means point 5 is included in the high category or it can be concluded that the regulation of smartphone usage in MEEP has not been maximal or even absent.

The observation data was reinforced by interviews with teachers and four students from each MEEP. Interviews were done with five teachers where the five teachers confirm that $97 \%$ of their students owned and used smartphones in the classroom. They argue that smartphone can help the learning process as well as interrupt the learning process because students were still passive in following the learning and students still consider the smartphone as a tool for entertainment and social media. They argued that smartphones interrupted students' focus on learning, students became addicted to smartphones, students actively used smartphones for online gaming/mobile games and even some students play games at all times, students become individualists and ignore the surroundings, eliminate interaction between friends and teachers, students are always not on time in doing homework this is allegedly because students also play online games late into the night, as a medium to cheat when the exam, students become less rest so lazy while learning practice and learning theory, students have no attitude polite and disrespectful to his friend. Teachers said that there was no official regulation on the use of smartphone in the classroom, so the rules were limited to individual teacher policy only.

The interview result that was conducted with the students indicated that all of the students used a smartphone during the learning process if instructed by the teacher to find teaching materials. However, when teachers were not instructed, they used the smartphone as entertainment (watching or playing games) and social media when learning clandestinely. All of the students used smartphones as social media and as many as 18 students used them to play games online and only used smartphones to learn if there are tasks or based on teacher's orders. 
A total of 10 students addicted to playing online games with the reason that the game is challenging and nice to play. While 10 other students play games only when there is no learning task. A total of 13 students always use the smartphone as a media to play games rather than looking for teaching materials with the duration of playing every day, even as many as 5 students play games until late at night. All of the students cannot stop to use smartphones as social media and games. They feel very dependent with smartphones. The results of interviews with students were still very limited because students cannot be open to tell the use of smartphones $100 \%$ in their lives. This is because the difficulties in making an assessment of self-assessment by reason of several factors.

To overcome the unhealthy use of smartphones by the students, the teachers give several suggestions such as giving the understanding about the positive and negative impact from the use of smartphone to the students, directing the students to become busy to search the learning materials using their smartphones, make the use of smartphones orderly by giving the schedule when they should use the smartphones and when they have to stop to use the smartphones. The teachers should always make a control of the students' learning and give the punishment to the students who do not use the smartphone orderly. The school party should make a regulation related to the use of smartphones at school in a healthy manner. The parents are also expected to be more sensitive to the children's activity at home in order to make a good control from school party and the parents.

Based on observations and interviews, the use of smartphones has not been fully able to help the learning process. The utilization of smartphones and internet in a healthy way is not well developed by many schools. This makes the smartphone has more negative impact than positive impact. Negative impact of the smartphone such as eliminating the focus of student learning is caused by the addiction to play online games and play social media that impact on the decreasing of the student achievement. In fact, the use of smartphones by students unhealthy not only decrease the students' achievement but also makes morale of students become ugly like students cannot be socialized well, students become insensitive to the environment, and even students become disrespectful towards teachers and have the likes insulting others.

\subsection{Discussion}

The use of smartphones by MEEP students in schools does not have a positive effect on the whole but is more dominated by its negative impact. Based on observations and interviews, the use of smartphones by MEEP students is more disturbing than to help the learning process. But the use of smartphones is actually very good as a learning media if it is used properly by students. For example, smartphones as learning media such as e-learning, media to run software such as ubiquitous learning, and Software Socrative. This is reinforced by a study of the utilization of smartphones connected to the internet that children aged 9-16 years using the internet as a tool to develop themselves provided face-to-face service [24]. On the other hand, the learning process more accommodated by the E-Books technology (digital books) that can be accessed from a smartphone that makes students and teachers do not have difficulty carrying a variety of books. E-Books make it easier for students and teachers to access and search for material with the right keywords. It is a convenience given smartphone in learning. However, the smartphone also provides features that can interfere with learning such as mobile games and social media are not controlled.

Based on interviews and observations, smartphones have a more dominant negative effect. This happens because students prefer to use smartphones as entertainment media such as mobile games and social media are not controlled. In effect, students become addicted to smartphones to not be able to control themselves. Students also become forgetful when it's time to play 
smartphones and when it's time to learn and which is more important between those things. In the learning process students become unfocused and they are tired to follow the learning process in the classroom. Negative impacts also occur on students' attitudes that are low in social terms, students also become insensitive to the environment, and students become dishonest by using smartphones as a means of cheating. The actual use of smartphones cannot be eliminated from MEEP students considering that they are people of the $\mathrm{Z}$ generation who are very familiar and dependent on technology. However, such student circumstances must be resolved immediately because internet addiction may degrade one's social capabilities [25]. Excessive use of smartphones also has a negative effect as a study that people who use smartphones excessively exert fatigue, sleep deprivation, and an unhealthy life [26]. Another study reinforces that teenagers in India who use smartphones compulsively affect the interpersonal and family relationships and sleep to be inadequate and unhealthy bodies [27].

The findings in this study are very contrary to previous studies that recommended smartphones as an effective learning media. However, it is not entirely wrong. Researchers see there is one side that becomes an important thing to be developed that is the rule about smartphone usage by student. Based on the interview results, the teacher recommended in accommodating the students to be given training on the use of a smartphone in healthy way. The parties involved not only from the school but also from the parents of students. There are many ways are offered to overcome these problems that can be done by developing applications anti-addiction smartphone [28]. The app allows students to access it directly. Application development can also be a game, a study of elementary school children that a "garbage disposal" game application can deliver material to students about organic and non-organic waste and students are also more focused on using this game as a learning media [29].

Another way is the attention of the family. Addiction to smartphones also occurs due to parents' carelessness, so it is needed the parents' attention to their children in directing them towards the healthy use of smartphones [30]. Teaching healthy smartphones can be done by the parents through daily interactions and through open communication [31]. Other alternatives that can be done to overcome the problem of smartphone use are by forced the restrictions, selfawareness and self-control, school factors, peer support, and professional services. Therefore, the school, parents, and society play an important role in shaping the attitude of students who can use smartphones in a healthy manner [32].

\section{Conclusion}

The utilization of smartphones in the learning process is very necessary to be considered that MEEP students are those of the $\mathrm{Z}$ generation who are very familiar with smartphones and also MEEP are a technology school that both become a power of its own. However, smartphone usage should always be monitored by teachers, schools, parents, and the community because the free use of smartphones by students has a negative impact on the learning process and student learning outcomes. Researchers found that students prefer to use smartphones as a media to play games and social media rather than as a learning media. This is because playing games and social media is more interesting than learning. Research on the characteristics of MEEP students from the Z-generation in detail is needed in the future as a basis for determining the learning process.

Researchers have an alternative way to overcome the use of negative smartphone that is by providing training in the use of smartphones for the students in schools, this training is also 
biased with the application of the use of smartphones in a healthy manner that can be downloaded by students. Another alternative is the presence of teachers, parents, and communities that must be involved in student education and oversee the healthy usage of a smartphone by the students. Alternatives are options that can be done in the short term where this alternative obviously has many weaknesses. The research which is done is also still has many shortcomings such as limited time and funds to select more samples and types of research that still shaped in a phenomenology.

Researchers recognize the need to develop a healthy smartphone learning model for students where the uses of smartphones to learn become more attractive for the students than games and social media. This is certainly not an easy matter, but it is very necessary and has a greater chance. The use of smartphones by students is not avoided bias because every year students who enter the MEEP are those who are increasingly familiar with the smartphones. They are from a new generation or Alpha generation so that teachers can only direct the use of smartphones in a healthy manner.

\section{References}

[1] Raphael, C., A: Internet History. Int. J. Technoethics. Vol. 2, pp. 45-64 (2011)

[2] Arulselvi, E.: Research Papers Effect Of Instructional Media In The Learning Of English Grammar On The Achievement Of Teacher Training Students At Namakkal District. English Language Teach. Vol. 1, pp. 80-87 (2011)

[3] Eunmo, S. and Richard, E., M.: Online multimedia learning with mobile devices and desktop computers: An experimental test of Clark's methods-not-media hypothesis. Computer Human Behav. Vol. 29, pp. 639-647 (2013)

[4] Kare, B.: Using smartphones to supplement classroom reading. Read Teach, Vol. 66, pp. 340-344 (2012)

[5] Bambang H., M., J., Dewiyani, S. Pantjawati, S.: Development of Web-Based Learning Application for Generation Z. Int. J. Eval. Res. Educ. Vol. 5, pp. 60-68 (2016)

[6] Mastura, A., Melor, A., and Mohd, R., R.: Utilization of Educational Technology to Enhance Teaching Practices: Case Study of Community College in Malaysia. In the Proceedings of Social and Behavioral Sciences. Vol. 195, pp. 1793-1797 (2015)

[7] Thosporn, S.: Instructional Design Framework for Educational Media. In the Proceedings of Social and Behavioral Sciences. Vol. 176, pp. 65-80 (2015)

[8] Elson, S., Annie, Y., C., and Jon, C., H.: Learning with Social Media: How do Preservice Teachers Integrate YouTube and Social Media in Teaching?. Asia-Pacific Educ. Res. Vol. 25, pp. 35-44 (2016)

[9] Moch, B., T.: The Indicators of Instructional Design for E- learning in Indonesian Vocational High Schools. Proceedings of Social and Behavioral Sciences. Vol. 204, pp. 54-61(2015)

[10] Dong, H., S., Youn, J., S., Hyunseung, C., and Khisu, B.: Smartphones as smart pedagogical tools: Implications for smartphones as u-learning devices. Computer Human Behav. Vol. 27, pp. 2207-2214 (2011)

[11] Viji, R., and Srinivasa, R.: Smartphones Promote Autonomous Learning in ESL Classrooms. Malaysian Online J. Educ. Techno. Vol. 3, pp. 23-35 (2015) 
[12] Muhammad, A., Mohammad, N., A., Masitah, S., Danang, K., W., dan Miftachul, H.: Smartphones usage in the classrooms: Learning aid or interference?. Educ. Inf. Technol. Vol. 22, pp. 3063-3079 (2017)

[13] David, M., C., and Josip, S.: Software Socrative and Smartphones as Tools For Implementation of Basic Processes of Active Physics Learning in Classroom: An Initial Feasibility Study With Prospective Teachers. Eur. J. Phys. Educ. Vol., 4, pp. 17-24 (2013)

[14] Tessa, J.: Students' cell phone addiction and their opinions. Elon J. Undergrad. Res. Commun. Vol. 5, pp. 74-80 (2014)

[15] Lusekelo, K., and Gervas.: Smartphones' Effects on Academic Performance of Higher Learning Students. J. Multidiscip. Eng. Sci. Technol. Vol. 2, pp. 777-784 (2015)

[16] Kimbrough, S., Culpepper, D., and Crutcher, T.: Students' Perception of Cell Phones in the Classroom. International Journal of Humanities Social Sciences and Education. Vol. 4, pp. 147-152 (2017)

[17] Rory, M., Kara, T., and John, L., C.: The impact of goal achievement orientation on student technology usage in the classroom. J. Comput. High. Educ. Vol. 29, pp. 240 266 (2017)

[18] Sami, H., Dannielle, L., Lihi, D., and Elena, S.: The effect of sleep disturbances and internet addiction on suicidal ideation among adolescents in the presence of depressive symptoms. In the Proceedings of Psychiatry Research. Vol. 267, pp. 327-332 (2018)

[19] Siew, F., N., Nor, S., I., C., H., Nor, H., M., N., and Nur, A., A., M.: The Relationship Between Smartphone Use and Academic Performance: A Case of Students in a Malaysian Tertiary Institution. Malaysian Online J. Educ. Technol. Vol. 5, pp. 58-70 (2013)

[20] Dana, G., Julie, A., G., Joon, C., Ann, E., R., and Lauren, H.: Racial/ethnic sleep disparities in US school-aged children and adolescents: a review of the literature. Sleep Heal. Vol. 4, pp. 68-80 (2018)

[21] Tim C.: Preparing Generation Z for the Teaching Professional. SRATE Journal. Vol, 27, pp. 1-8 (2018)

[22] Yanuar, S., P.: Theoritical Review : Teori Perbedaan Generasi. Journal Ilmiah Among Makarti. Vol. 9, pp. 123-134 (2017)

[23] Grail Research 2011 http://www.integreon.com/pdf/Blog/Consumers_of_Tomorrow_Insights_and_Observa tions_About_Generation_Z_246 (Accessed 20 February 20108).

[24] Siti, Z., O., Azlina, D., Md. S., H., Jusang, B., and Misha, T.: Children Internet Usage: Opportunities for Self Development. Proceedings of Social and Behavioral Sciences. Vol. 155, pp. 75-80 (2014)

[25] Mahapatra, A., and Sharma, P.: Association of Internet addiction and alexithymia - A scoping review. Addict. Behav. Vol. 81, pp. 175-182 (2018)

[26] Alosaimi, F., D., Alyahya, H., Alshahwan, H., Al-Mahyijari, N., and Shaik, S., A.: Smartphone addiction among university students in Riyadh, Saudi Arabia. Saudi Media Journal. Vol. 37, pp. 675-683(2016)

[27] Abinash, P., and Nikunj, K., J.: Compulsive smartphone usage and users' ill-being among young Indians: Does personality matter?. Telemat Informatics, xxx xxx-xxx (2018) 
[28] Myounghee, S., and Kangwoo, L.: Measuring smartphone usage time is not sufficient to predict smartphone addiction. Journal of Theory Application Inf Technology. Vol. 95, pp. 5296-5303 (2017)

[29] Imanuel, V., C., and Arie, S., P.: Developing Board Game as Learning Media about Waste Sorting for Fourth Grade Students of Elementary School. Journal Prima Edukasia. Vol. 6, pp. 78-88 (2018)

[30] Kwak, J., Y., Kim, J., Y., and Yoon, Y., W.: Effect of parental neglect on smartphone addiction in adolescents in South Korea . Child Abus Negl. Vol. 77, pp. 75-84 (2018)

[31] Katrien, S., Koen, P., Michel, W., and Wannes, H.: A qualitative study into parental mediation of adolescents' internet use. Comput. Human Behav. Vol. 73, pp. 423-432 (2017)

[32] Januariyansah, S. and Rohmantoro, D' The Role of Digital Classroom Facilities to Accommodate Learning Process of The $\mathrm{Z}$ and Alpha Generations. Proceeding of International Conference on Child-Friendly Education, pp. 434-439 (2018) 